\title{
A NOVEL METHOD FOR STATISTICAL PATTERN RECOGNITION USING THE NETWORK THEORY AND A NEW HYBRID SYSTEM OF MACHINE LEARNING
}

\author{
NOVA METODA ZA RAZPOZNAVANJE STATISTIČNIH VZORCEV \\ Z UPORABO TEORIJE OMREŽIJ IN NOV HIBRIDNI SISTEM \\ STROJNEGA UČENJA
}

\author{
Matej Babič ${ }^{1}$, Dragan Prsić², Zoran Jurković3 ${ }^{3}$ Borbás Lajos ${ }^{4}$, Sanda Ipšič-Martinčić5 \\ Lenka Lhotská6, Lanndon Ocampo \\ ${ }^{1}$ Jožef Stefan Institute, Jamova 37, Ljubljana, Slovenia \\ ${ }^{2}$ Faculty of Mechanical and Civil Engineering, Kraljevo, Serbia \\ ${ }^{3}$ University of Rijeka, Croatia \\ ${ }^{4}$ Budapest University of Technology and Economics, Hungary \\ 5 University of Rijeka, Croatia \\ ${ }^{6}$ Czech Technical University in Prague, Czech \\ ${ }^{7}$ Cebu Technological University, Philippines
}

Prejem rokopisa - received: 2018-06-07; sprejem za objavo - accepted for publication: 2018-10-12

doi:10.17222/mit.2018.116

\begin{abstract}
The increase in wear resistance of cast irons after laser treatment is due not only to the corresponding structural and phase composition, but also to the improvement in the friction conditions due to the graphite retained in the laser impact zone. Also, laser hardening increases the wear resistance of steels and some other alloys in terms of the friction in alkaline and acidic environments. In this article we present a new method for a hybrid system of machine learning using a new method for statistical pattern recognition through network theory in robot laser hardening (RLH). We combined the method of multiple regression, the method of a support vector machine and the method of a neural network. For statistical pattern recognition we use the topological properties of network theory. The even distribution of the topological property $16-300$ triads throughout the various levels of the organization and network in the microstructure of RLH indicates that there is a strong linkage across the network and an active connection among the needles of martensite.

Keyword: hybrid machine learning, statistical pattern recognition, network theory, fractals

Povečanje obrabne odpornosti litega železa po laserski obdelavi je posledica ne le ustrezne strukturne in fazne sestave, temveč tudi izboljšanja pogojev trenja zaradi grafita v območju laserja. Lasersko kaljenje poveča tudi odpornost proti obrabi jekel in nekaterih drugih zlitin s stališča trenja v kislem in alkalnih okoljih. Avtorji predstavljajo novo metodo hibridnega sistema strojnega učenja z uporabo nove metode za prepoznavanje statističnih vzorcev s teorijo omrežja pri robotnem laserskem kaljenju $(\mathrm{RLH})$. Združili so metodo multiple regresije, metode podpornih vektorjev in metodo nevronskih mrež. Za prepoznavanje statističnih vzorcev so uporabili topološke lastnosti teorije omrežja. Enakomerna porazdelitev topoloških lastnih 16-300 triad v različnih ravneh organizacije in mreže $v$ mikrostrukturi RLH kaže, da obstaja močna povezava preko omrežja in aktivna povezava med iglicami martenzita.

Ključne besede: hibridno strojno učenje, statistično razpoznavanje vzorcev, teorija omrežij, fraktali
\end{abstract}

\section{INTRODUCTION}

The robot laser hardening $(\mathrm{RLH})^{1}$ (i.e., thermal hardening by laser radiation) of metals and alloys by laser radiation is based on local heating of a surface area under the influence of radiation and subsequent cooling of the same area with a supercritical velocity as a result of the removal of the heat into the inner layers of the metal. Laser hardening is a process of projecting features such as a non-controlled energy intake, high-performance constancy, and an accurate positioning process. It is used exclusively on ferrous materials suitable for hardening, including steel and cast iron with a carbon content of more than $0.2 \%$. The high hardness of the

*Corresponding author e-mail

babicster@gmail.com martensite microstructure provides improved properties, such as wear resistance and strength. A study of the microstructures and performance are very important in materials science. ${ }^{2}$ For a laser heat treatment, a $\mathrm{CO}_{2}$ laser with a high-power continuous mode was used. In contrast to the known heat-hardening processes, quenching by high-frequency currents, its own specific features, when a laser heat treatment is adopted. The main goal of the laser thermal hardening of steel cast irons and nonferrous alloys is to increase the wear resistance of parts working under friction conditions. As a result of the laser hardening, a high surface hardness, a high structure dispersion, a reduction of the friction coefficient, an increase in the bearing capacity of the surface layers and other parameters is achieved. Laser hardening provides the lowest wear and friction coefficient, while hardening 
in a furnace provides the largest. Fractal ${ }^{3}$ material science works by an attempt to establish the relationship between the parameters of fractal structures and the dissipative properties of a tool steel. The Hurst exponent $H^{4}$ is one of the most frequently used statistics to describe a weakly stationary stochastic process that has a long memory. The connection with the Hurst exponent $H$ and the fractal dimension $D$ in $3 D$ space can be described with the equation $D=3-H$. This equation can be applied in the mechanical engineering domain, particularly in the laser-hardening technique. ${ }^{5}$ Pattern recognition $^{6}$ is a scientific direction related to the development of principles and the construction of systems designed to determine the belonging of a given object to one of the pre-designated classes of objects. The task of image search with a pattern is part of the sub-tasking of a more general pattern-recognition task. With an unsystematic and non-directional search for "similar" objects from a variety of objects, they can be enumerated indefinitely with a given probability. In particular cases, objects are characterized by such identification parameters (characteristics) as shape, color, position, mobility, by distinctive features, their combinations, among others. Statistics $^{7}$ is a measurable numerical function from a sample that does not depend on unknown distribution parameters. In a broad sense, the term (mathematical) statistics denotes the field of knowledge (and its corresponding disciplines) that outlines the general issues of collecting, measuring and analyzing mass statistical (quantitative or qualitative) data. Machine learning, ${ }^{8}$ on the other hand, is an extensive subsection of artificial intelligence that studies methods of constructing algorithms capable of learning. There are two types of training. Learning by the use of precedents, also known as inductive learning, is based on the identification of general patterns of private empirical data. Machine learning is at the intersection of mathematical statistics, optimization methods, and classic mathematical disciplines. However, it also has its own specific characteristics related to problems of computational efficiency and retraining. Network theory ${ }^{9}$ is another name for graph theory, which is applied primarily to computer networks. Note that graph theory is a section of discrete mathematics that concerns the properties of graphs, where the graph is represented by a set of vertices (nodes) connected by edges or arcs. The word "network" is intuiti-

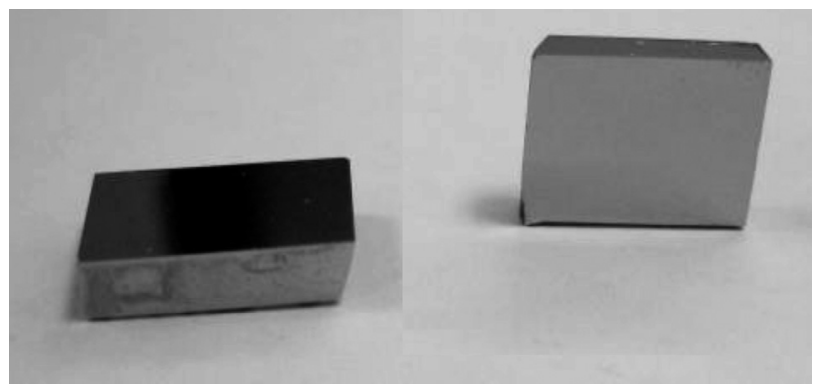

Figure 1: Robot-laser-hardened specimen vely much more understandable than the word "graph"; thus, the term "network theory" is now often used in various types of research domains - from sociological ones, such as the study of crowd behavior or the study of political preferences, to studies of climatology. This paper aims to outline the possibilities of applying a new method of a hybrid system of machine learning using a new method for statistical pattern recognition by way of a network theory for the prediction of RLH heat.

\section{MATERIALS PREPARATION, METHODOL- OGY AND STATISTICAL ANALYSIS}

Figure 1 presents a robot-laser-hardened specimen, while Figure 2 presents the needle of a martensite microstructure of a RLH specimen.

For statistical pattern recognition, the network theory approach is used. Firstly, we convert SEM images (Figure 3a) into binary pictures (Figure 3b). Black pixels represent the number 0 , while white pixels represent the number 1 . Most of the tasks on graphs concern the definition of connectivity components, finding routes, finding distances, among others. When they are numerically solved on a computer, the graph must be represented in some discrete way. One of the directions of graph theory is the capability of graphs to be represented by algebraic form matrices. This representation of graphs is convenient for solving many practical problems. In Figure 3c and $\mathbf{3 d}$ we consider such representations. The adjacency matrix of an oriented graph with $n$ vertices is the matrix $A=\left[a_{i j}\right], i, j=1, \ldots, n$, in which $a_{i j}=1$, if there exists an edge $\left(x_{i}, x_{j}\right)$ and $a_{i j}=0$ if the vertices $x_{i}, x_{j}$ are not connected with the edge $\left(x_{i}, x_{j}\right)$. The adjacency matrix uniquely determines the structure of the graph. The loop-type edge in the adjacency matrix is represented by the corresponding unit diagonal element. The main disadvantage of representing the graph with the adjacency matrix is the impossibility of representing multiple edges. For the graph in Figure 3d, we calculate the

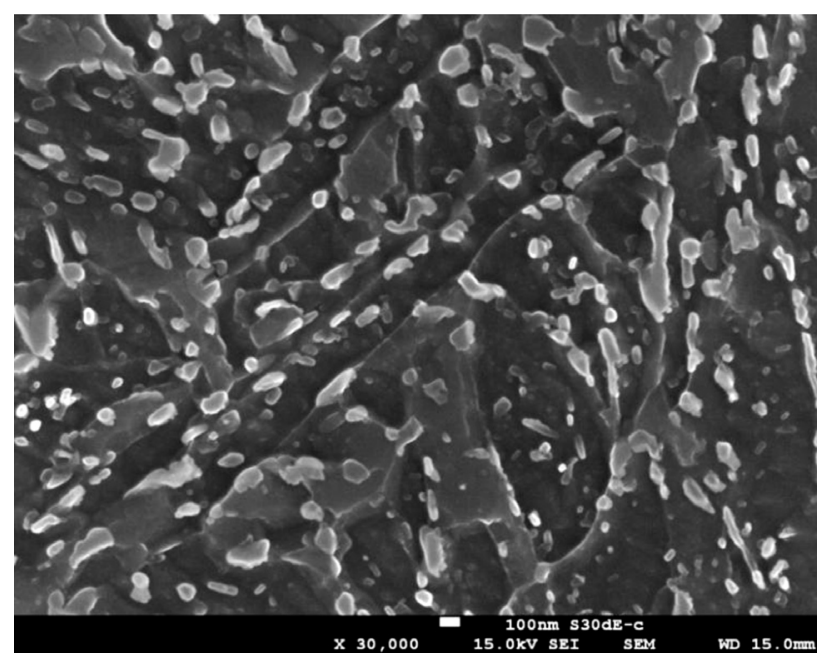

Figure 2: Microstructure of RLH specimen 


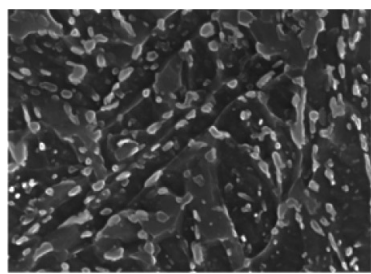

a)

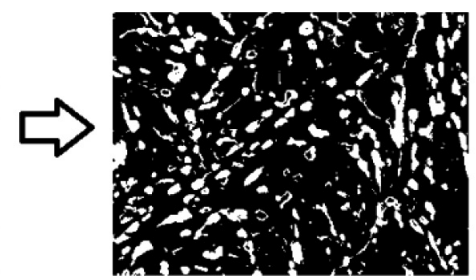

b)

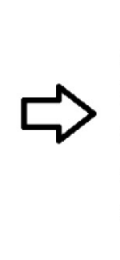

\begin{tabular}{l|lllll}
\multicolumn{1}{l}{} & a & b & $c$ & $d$ & e \\
\cline { 2 - 6 } & 0 & 1 & 1 & 1 & 0 \\
b & 1 & 0 & 0 & 1 & 0 \\
c & 1 & 0 & 0 & 0 & 0 \\
d & 1 & 1 & 0 & 0 & 1 \\
e & 0 & 0 & 0 & 1 & 0
\end{tabular}

c)

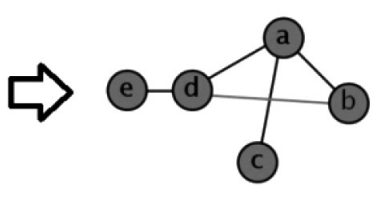

d)

Figure 3: New method for statistical pattern recognition using network theory

statistical topological properties; namely, the average degree and triadic census - type 16300.

We calculated the complexity, fractal dimension of hardened specimens by using a new method for estimating the Hurst exponent $\mathrm{H}$ for $3 \mathrm{D}$ objects. ${ }^{10}$

For the analysis of the results we used intelligent system methods, ${ }^{11}$ i.e., multiple regression, ${ }^{12}$ neural network ${ }^{13}$ and support vector machine. ${ }^{14}$ Intelligent systems are meant to be adaptive, i.e., to solve problems as creatively as possible with minimal human input. The system identifies and defines the problem.

The main purpose of multiple regression is to build a model with a large number of factors while determining the impact of each of them separately as well as their combined effects on the modeled indicator. The multiple regression equation is represented by

$$
y=f(X 1, X 2, \ldots, X m)+E
$$

where $y$ is the dependent variable (the resultant attribute), $X 1, X 2, \ldots, X \mathrm{~m}$ are independent explanatory variables (feature factors), and $E$ is a perturbation or stochastic variable that includes the influence of unaccounted factors in the model.

Various differences exist between the neural network models used by machine-learning researchers and those used by computational neuroscientists. This is in part because the objective of the former is to obtain compu-

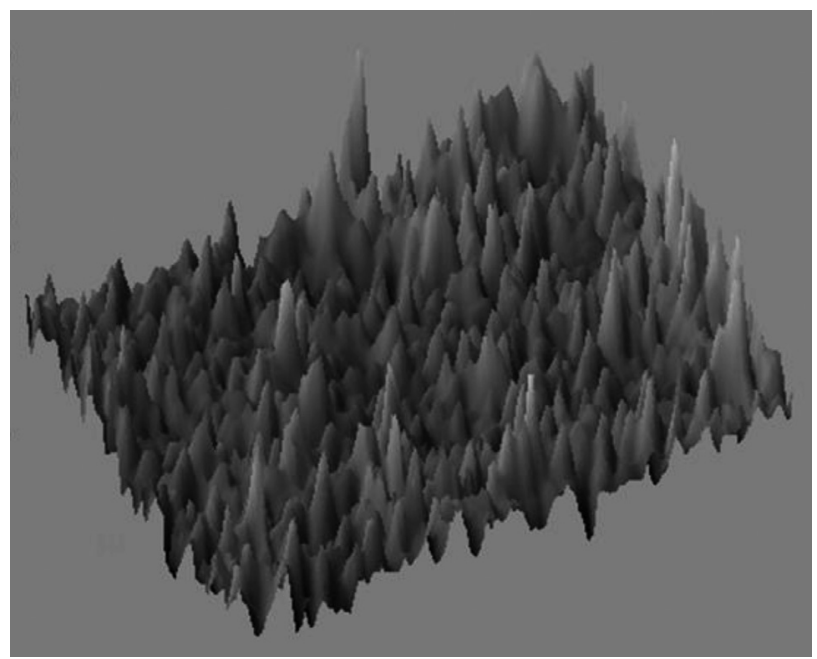

Figure 4: The $3 D$ object of a robot-laser-hardened microstructure tationally efficient learners that generalize well to new examples, whereas the objective of the latter is to abstract neuroscientific data while obtaining explanations of the associated principles, providing predictions and guidance for future biological experiments. Neural networks use two sets of data: the training set and the test set. The training set is the set of examples that are used to train the neural network. The test set is a "control" that allows the user to observe how the network can generalize the training set to other data. Figure 5 presents the model of the neural network. We use a backpropagation, 4-layer, neural network. The speed of learning was 0.5 , the inertial coefficient was 0.6 , the test mass tolerance was 0.03 and the tolerance of the learning set was 0.02 .

The arsenal of methods for the cluster analysis and pattern recognition of data-mining systems usually includes the support-vector-machine (SVM) method, the decision-trees method, the nearest-neighbor method in feature space, and the Bayesian classification, among others. Among the mentioned group of methods of classification and recognition, the method of support vector machine is the most interesting and flexible one. SVM is a method of initial classification that solves the problem by constructing hyperplanes in a multidimensional space that separate the observation groups belonging to different classes. Figure 6 illustrates the basic principle of the SVM. In the left-hand part of the diagram, the original objects are represented, which are further transformed (moved, shifted) in the feature space using a special class of mathematical functions called kernels. This process of displacement is also called a transformation, or regrouping, of the objects. A new set of transformed objects (on the right-hand side of the diagram) is already linearly divided. Thus, instead of constructing a complex curve (as shown in the left-hand part of the diagram), it is only necessary to draw an optimal line that will separate the objects of different types. The method then searches for objects that are on the boundaries between two classes, called support vectors, and uses them to decide whether or not they belong to a class of new objects to be recognized. We use the v-SVM Type with a regression cost (C) 1.00. For the optimization parameters, we use a 100 iteration limit and 


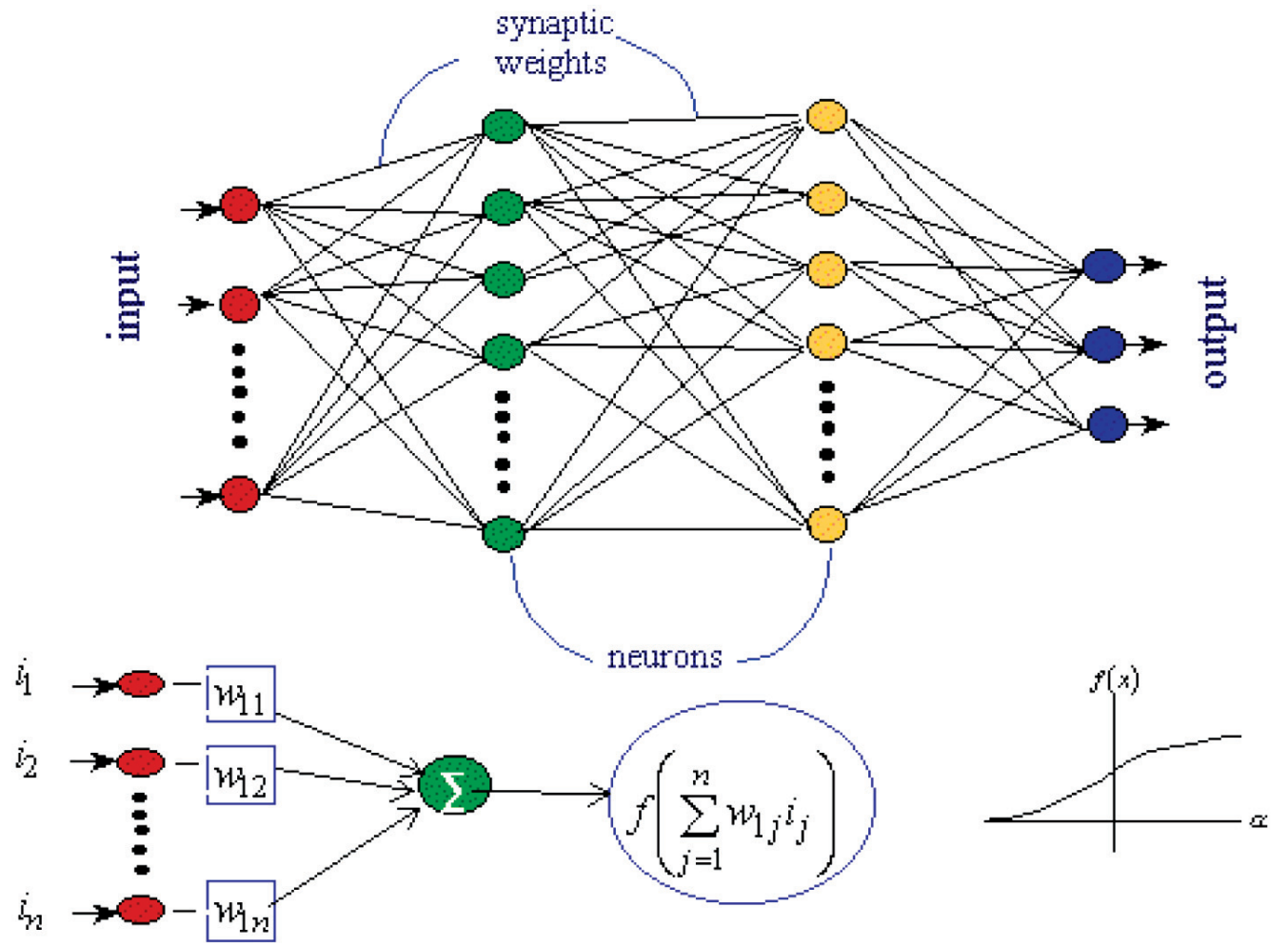

Figure 5: Model of the neural network

a numerical tolerance of 0.001 . We use the Kernel $(\mathrm{g} \times \mathrm{x} \times \mathrm{y}+0.13)^{3}$ where $\mathrm{g}$ was auto.

The hybrid methods ${ }^{15}$ of machine learning are techniques that create multiple models and then combine them to give improved results. These methods usually produce more accurate solutions than single models. This has been the case for a number of machine-learning competitions, where the winning solutions adopted hybrid methods. In this article we present a new method

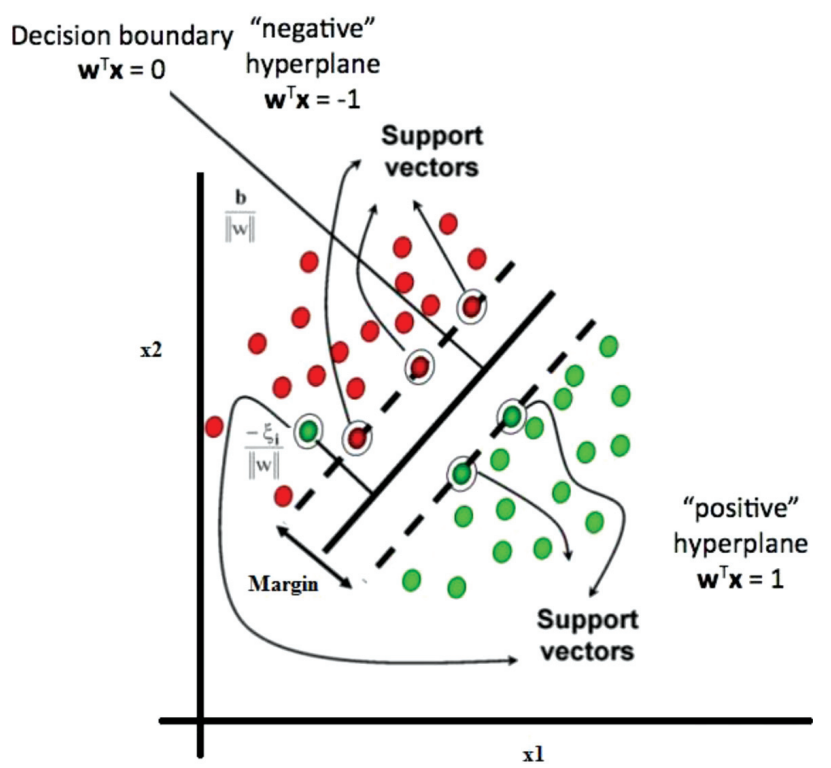

Figure 6: The basic idea of the support-vector method of the hybrid system of machine learning for the prediction of surface mechanical properties. We combined method 1 (i.e., multiple regression), method 2 (i.e., support vector machine) and method 3 (i.e., present neural network). Figure 6 demonstrates the new hybrid method of machine learning.

\section{RESULTS AND DISCUSSION}

In Table 1 the parameters of the hardened specimens that impact on the hardness are presented. We marked the specimens from D1 to D20. Parameter P1 represents the temperature $\left({ }^{\circ} \mathrm{C}\right), \mathrm{P} 2$ represents the speed of the hardening $(\mathrm{mm} / \mathrm{s}), \mathrm{P} 3$ represents the fractal dimension that is calculated using the new method of estimating the Hurst parameter in 3D space, $\mathrm{P} 4$ represents the statistical topological property average degree, and P5 represents the topological property triadic census - type 16-300. The last parameter $\mathrm{Y}$ is the measured hardness of the laser-hardened robot specimens. The initial hardness before hardening was $34 \mathrm{HRc}$. With the fractal dimension we were able to describe the complexity of the hardened specimens. In Table 1 we can see that specimen D15 has the largest fractal dimension (2.433). Thus, specimen D15 emerges as the most complex specimen. Specimen D1 has the largest hardness value after hardening, i.e., 60 HRc. Specimen D22 has the maximum average degree 10.938713. Specimen D20 has the maximum triadic census - type 16-300; 7284078. 
M. BABIČ et al.: A NOVEL METHOD FOR STATISTICAL PATTERN RECOGNITION USING THE NETWORK THEORY ...

Table 1: Parameters of the hardened specimens

\begin{tabular}{|c|c|c|c|c|c|c|}
\hline S & P1 & P2 & P3 & \multicolumn{1}{|c|}{ P4 } & P5 & Y \\
\hline D1 & 1000 & 2 & 2.304 & 6.67524381 & 4865624 & 60 \\
\hline D2 & 1000 & 3 & 2.264 & 6.31098938 & 4191425 & 58.7 \\
\hline D3 & 1000 & 4 & 2.258 & 6.36264992 & 4267175 & 56 \\
\hline D4 & 1000 & 5 & 2.341 & 6.40055656 & 4353872 & 56.5 \\
\hline D5 & 1400 & 2 & 2.222 & 6.32171059 & 4212248 & 58 \\
\hline D6 & 1400 & 3 & 2.388 & 6.08444405 & 3796016 & 57.8 \\
\hline D7 & 1400 & 4 & 2.25 & 6.31554222 & 4196282 & 58.1 \\
\hline D8 & 1400 & 5 & 2.286 & 6.05316353 & 3741603 & 58.2 \\
\hline D9 & 1000 & 2 & 2.178 & 6.39926147 & 4256560 & 57.4 \\
\hline D10 & 1000 & 3 & 2.183 & 6.45902824 & 4483986 & 56.1 \\
\hline D11 & 1000 & 4 & 2.408 & 6.32466888 & 4207031 & 53.8 \\
\hline D12 & 1000 & 5 & 2.210 & 6.40055656 & 4353872 & 56 \\
\hline D13 & 1400 & 2 & 2.257 & 6.58311844 & 4862060 & 55.3 \\
\hline D14 & 1400 & 3 & 2.265 & 7.0289135 & 5877473 & 57.2 \\
\hline D15 & 1400 & 4 & 2.433 & 6.36786461 & 4199754 & 57.8 \\
\hline D16 & 1400 & 5 & 2.289 & 7.12132263 & 5848517 & 58 \\
\hline D17 & 800 & 0 & 2.232 & 6.06192017 & 3774789 & 52 \\
\hline D18 & 1400 & 0 & 2.235 & 6.07022095 & 3819193 & 57 \\
\hline D19 & 2000 & 0 & 2.261 & 6.04652596 & 3746658 & 56 \\
\hline D20 & 950 & 0 & 2.282 & 7.91842079 & 7284078 & 58 \\
\hline
\end{tabular}

In Table 2 the experimental and prediction data are presented. The first column presents the name of the specimens, while the second column presents the experimental data. For the prediction of the hardness, we use one live out method of the neural network. The predictions with multiple regression are presented in column $\mathrm{MR}$, the predictions with the neural network are presented in column NN, the predictions with the support vector machine are presented in column SVM, and the predictions with the hybrid method of machine learning are presented in column $\mathrm{H}$.

The measured and predicted surface hardness of the RLH specimens are shown in Figure 7. The multiple regression model presents a $2.0 \%$ deviation from the measured data. The neural network model presents a $2.79 \%$ deviation from the measured data. The support vector machine model presents a $2.76 \%$ deviation from the measured data. The hybrid method of machine learning presents a $3.05 \%$ deviation from the measured data. The multiple regression model is presented by Equation (1).

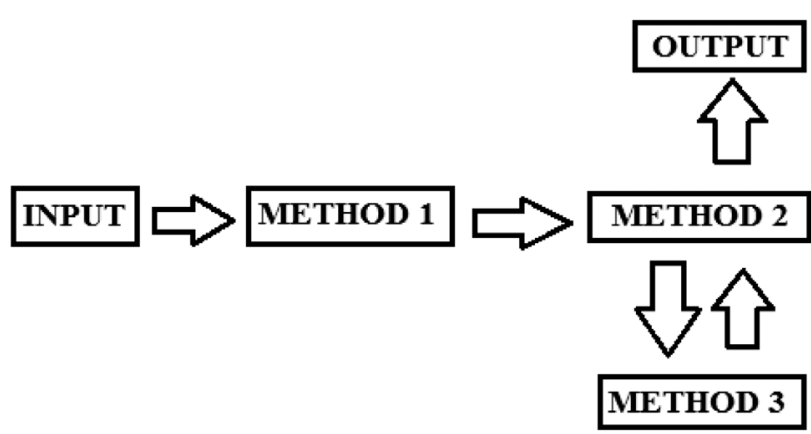

Figure 6: Hybrid method of machine learning
Table 2: Experimental and prediction data

\begin{tabular}{|c|c|c|c|c|c|}
\hline S & E & MR & NN & SVM & H \\
\hline D1 & 60 & 56.2 & 58.0 & 58.7 & 56.2 \\
\hline D2 & 58.7 & 56.2 & 56.0 & 60.0 & 58.6 \\
\hline D3 & 56 & 56.7 & 58.0 & 58.1 & 58.6 \\
\hline D4 & 56.5 & 56.7 & 57.0 & 58.2 & 56.1 \\
\hline D5 & 58 & 57.4 & 57.8 & 57.2 & 56.2 \\
\hline D6 & 57.8 & 56.3 & 57.8 & 57.8 & 56.1 \\
\hline D7 & 58.1 & 57.8 & 56.0 & 58.2 & 56.2 \\
\hline D8 & 58.2 & 57.0 & 56.0 & 58.1 & 56.1 \\
\hline D9 & 57.4 & 57.2 & 56.0 & 56.1 & 56.2 \\
\hline D10 & 56.1 & 56.6 & 57.0 & 57.4 & 56.3 \\
\hline D11 & 53.8 & 56.1 & 57.8 & 57.8 & 56.2 \\
\hline D12 & 56 & 57.1 & 56.1 & 57.0 & 58.6 \\
\hline D13 & 55.3 & 56.5 & 58.0 & 57.2 & 56.4 \\
\hline D14 & 57.2 & 56.3 & 58.0 & 58.1 & 56.2 \\
\hline D15 & 57.8 & 58.1 & 57.8 & 57.8 & 58.6 \\
\hline D16 & 58 & 58.6 & 57.2 & 55.3 & 57.2 \\
\hline D17 & 52 & 53.9 & 57.0 & 57.0 & 57.4 \\
\hline D18 & 57 & 55.6 & 54,6 & 60.0 & 55.7 \\
\hline D19 & 56 & 57.6 & 57.6 & 58.1 & 57.4 \\
\hline D20 & 58 & 58.3 & 56.0 & 57.8 & 56.2 \\
\hline & & & & & \\
\hline
\end{tabular}

$\mathrm{Y}=\mathrm{D} 1 \times 3.254102147 \times 10^{-3}+\mathrm{D} 2 \times 2.497835937 * 10^{-1}$

D3×3.109135899 + D4×17.99474612-

D $5 \times 8.350816582 \times 10^{-6}-19.30747675$

The 16-300 triad is a completed triad of three mutual dyads. This triad provides a measure of the extent to which the global organization of the relationship is an interlocking pattern of bonding, which is connecting virtually everyone. The even distribution of 16-300 triads throughout the various levels of the organization and network in the microstructure of the RLH indicates that there is a strong linkage across the network and an active connection among the needles of martensite. An average degree means an average number of links per node. The more black pixels (number 1 in Figure 3) we have, the

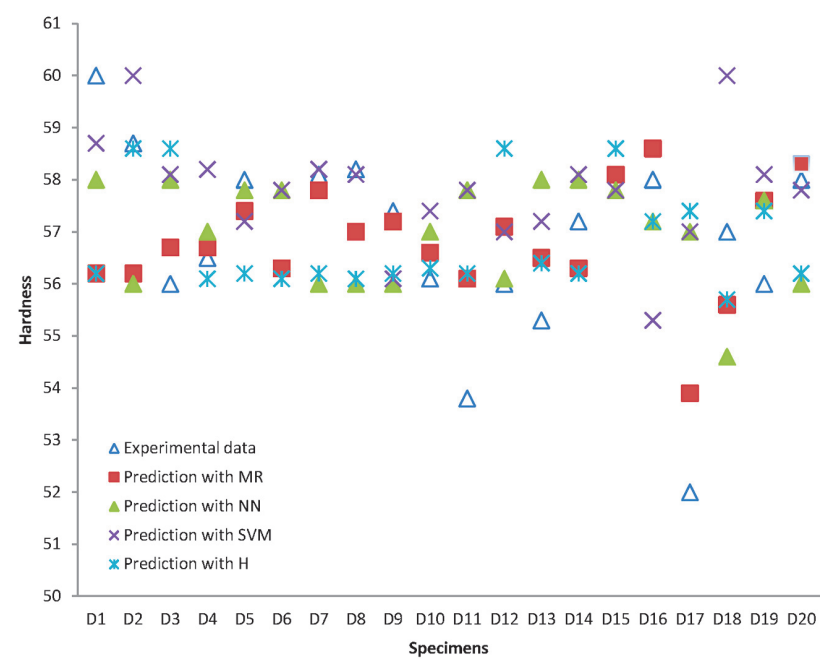

Figure 7: Measured and predicted hardness of the hardened specimens 
higher the average degree of the network is. We can see that gives us computer performance as a hybrid prediction model compared to known models' worse results. But the new hybrid method of machine learning can contribute to both artificial intelligence and applications in some different area.

\section{CONCLUSION}

The main goal of the laser thermal hardening of steel, cast irons and non-ferrous alloys is to increase the wear resistance of parts working under friction conditions. The hardness structure of a material is an important mechanical property that affects the hardness of materials. As a result of laser quenching, a high surface hardness, a high structure dispersion, a reduction of the friction coefficient, an increase in bearing capacity of the surface layers and other parameters are achieved. Laser hardening provides the lowest wear and friction coefficient, and hardening in the furnace, the largest. Along with this, laser quenching is characterized by very little run-in (only two or three cycles), a decrease in the upper values of the number of pulses of acoustic radiation, and a small interval of the change in the number of pulses. This is due to an increase in the homogeneity of the microstructure of the surface region after laser hardening. The paper presents a new method for the hybrid system of machine learning using a new method for a statistical pattern recognition of the microstructure of RLH. We use network theory to describe the needle of a martensite structure in the microstructure of RLH specimens.

\section{REFERENCES}

${ }^{1}$ M. Sato, Y. Adachi, H. Motoyama, Application of laser hardening technology to sintered parts, Sei Technical Review, 82, (2016), 66-69

${ }^{2}$ X. Zong, W. Jiang, Z. Fan. A study of the microstructures and performance of chromium boride coatings on aisi 52100 steel, Mater. Tehnol., 52 (2018) 2, 225-229
${ }^{3}$ C. C. Barton, Fractal analysis of scaling and spatial clustering of fractures, Barton, C.C. and LaPointe, P.R. (eds.), Fractals in the earth sciences, Plenum Press. New York, 1995, 141-178

${ }^{4}$ S. Yu, X. Piao, J. Hong, N. Park, Bloch-like waves in random-walk potentials based on supersymmetry, Nature Communications. 6 (2015) 8269, doi:10.1038/ncomms9269

${ }^{5}$ S. Žagar, J. Grum, Surface integrity after mechanical hardening of various aluminium alloys. Strojniški vestnik, 57 (2011), 4, 334-344, doi:10.5545/sv-jme.2010.092

${ }^{6}$ S. Manivannan, W. Li, S. Akbar, R. Wang, J. Zhang, S. J. McKenna, An automated pattern recognition system for classifying indirect immunofluorescence images of HEp-2 cells and specimens, Pattern Recognition, 51 (2016), 12-26

${ }^{7}$ J.-W. Romijn, Philosophy of statistics, Stanford Encyclopedia of Philosophy, 2014

${ }^{8}$ T. Simonite, Microsoft says its racist chatbot illustrates how AI isn't adaptable enough to help most businesses, MIT Technology Review, https://news.gotchamobi.com/category/artificial-intelligence/14558/ microsoft-says-its-racist-chatbot-illustrates-how-ai-isn-t-adaptable-e nough-to-help-most-businesses, 10.04.2017

${ }^{9}$ S. Sudhahar, GA Veltri, N. Cristianini, Automated analysis of the US presidential elections using Big Data and network analysis. Big Data \& Society. 2 (2015) 1, 1-28

${ }^{10} \mathrm{M}$. Babič, et. al. A new method for estimating the Hurst exponent $\mathrm{H}$ for 3D objects, Mater. Tehnol., 48 (2014) 2, 203-208

${ }^{11}$ T. Simonite, 2014 in Computing: Breakthroughs in Artificial Intelligence, MIT Technology Review, https://www.technologyreview.com/s/533686/2014-in-computing-breakthroughs-in-artificialintelligence/, 10.04.2017

${ }^{12}$ R. Alvin, C. C. William F., Chapter 10, Multivariate regression Section 10.1, Introduction, Methods of Multivariate Analysis, Wiley Series in Probability and Statistics, 709 (3rd ed.), John Wiley \& Sons, 2012, 19

${ }^{13}$ S. Jürgen, Deep learning in neural networks: An overview, Neural Networks, 61 (2015), 85-117, doi:10.1016/j.neunet.2014.09.003

${ }^{14}$ L. Barghout. Spatial-taxon information granules as used in iterative fuzzy-decision-making for image segmentation. granular computing and decision-making, Springer International Publishing, 2015, 285-318

${ }^{15}$ P. Kazienko, E. Lughofer, B. Trawiński. Hybrid and Ensemble Methods in Machine Learning, J.UCS Special Issue, Journal of Universal Computer Science, 19 (2013) 4, 457-461 